\title{
Hegemonious Treatment In Educating Children In Churches
}

\author{
Surbakti Tirsanika \\ \{tirsanikasurbakti@gmail.com\} \\ Postgraduate Program, Pelita Kebenaran School of Theology
}

\begin{abstract}
Every behavior that a child is exposed to can be imitated by the child. By the same token, parental behavior will influence positive development of children, while bad behavior can create bad children by children. Child development is influenced by the surrounding behavior including the language received by children in the family and the social environment. Authority in the family environment can affect the pattern of child development, depending on the behavior taught by parents. The purpose of this study is to know the effect of parental authority on the development of children to have a religious and spiritual life, to know the parents' strategies for children's development. Patterns and attitudes of parents in educating their children, which includes parental control of children, parents' democratic attitudes toward children, parents' demands on children, parents' affection for children through authoritarian, permissive or democratic ways.
\end{abstract}

Keywords: Power, Parents, Parenting

\section{Introduction}

Hegemony is a power or domination over the values of life, norms, and culture of a group of people which eventually turns into a doctrine of other groups of people where the dominated group consciously follows it.

Church education is one of the institutions that are trusted by the community to educate children in accordance with their religious beliefs. Education in the church raises religious hegemony in society having a doctrinal side of positive values that emphasize moral moral teachings.

In everyday life, we can see various kinds of behavior, various kinds of parental characters, and various levels of language used by parents in educating children. Not a few in the community where parental upbringing is still very authoritarian, can even be said to be hard in educating children. It does not rule out the possibility of parents' way of educating their children about discipline and compliance. Indeed, if you position yourself as a parent, 
there will be no one wrong in educating children, it's just that the parents are not really educated.

Power is essentially influence, influence is a process affecting other parties to carry out what is the purpose of the perpetrator. To achieve this goal, it takes effort or intermediary to achieve the goal, namely language. Power can be said as a person's ability to control the attitudes of others. The influence of leadership, also known as hegemony, is a power or domination of the values of life, norms, or the culture of individuals / groups of people that eventually turn into a doctrine of individuals / groups of society. This predominantly individual / group consciously follows the rules of the dominating group.

Thus, it can be understood that parental behavior will determine the direction of child development indirectly. Because this process does not just appear in the behavior of a child, behavior or the consequences of parenting mistakes will be very clear when the child begins to recognize himself, the environment, or understand each other's character. However, true power is used as a way to educate children so that children's development is still in the path of truth, politeness, discipline, religiosity. This will sometimes affect the responses of different children, so that not a few children assume that their parents educate them very hard or curb. The impact of this actually depends on parental behavior and also the acceptance of children in accepting the surrounding behavior.

\section{Research method}

This research is a descriptive study that uses a qualitative analysis approach. This study intends to describe the phenomenon of change in mind, attitude, and behavior of foster parents in the pattern of child learning. Researchers can get a clear picture of the phenomenon of changes in the mind, attitudes, and behavior of parents towards child development. This study investigates the behavior of parents in educating children in connection with the growth and development of children. The data was collected in the form of written words from speakers or observed partners.

\section{Results and Discussion}

Parenting is a model or way of parents in treating children, guiding, and disciplining and protecting children in achieving the maturation process, so that they are able to adapt to the prevailing norms in society. This form of parenting is by giving attention or facilities to support the development process of children to adulthood. Parenting is a process of parent interaction with children, in providing education by using various and appropriate methods so that children develop and socialize in accordance with the norms that apply in society.

Family is the first institution in a child's life in which he learns to be social beings. In families, children have close interaction with parents. Thus parenting plays an important role in children's lives. The church also has a role in equipping parents with God's Word, and consequently families can fulfill God's will in His Word.

The church is the body of Christ that complements and builds together to achieve a goal in Jesus Christ. The church can not separated from teaching, education and guidance, both to parents, elders, youth, adolescents, and children. In this case, the church must be active in developing spirituality, not only theory. 
There are 3 kinds of parenting styles, namely authoritarian, authoritative, and permissive.

1) Authoritarian parenting. Authoritarian parenting is a style that limits and punishes parents by children, where parents urge children to follow their instructions. Parents are authoritarian in placing strict limits and control on children.

2) authoritative parenting (authoritative / democratic parenting)

Democratic care encourages children to be independent, but parents can still provide limits and control to children. When children get problems parents can be a good place for discussion for children. Children are also given the freedom to express opinions, this type of parent shows support in response to child development behavior in finding their true identity.

3) Permissive Parenting

In this parenting style, parents give freedom to children in carrying out their activities, this type of parent has low control of the child and rarely punishes the child.

Table 1. Parenting Styles

\begin{tabular}{lll}
\hline Parental Style & \multicolumn{1}{c}{ Type } & \multicolumn{1}{c}{ Characteristics of Children } \\
\hline Authoritarian & $\begin{array}{l}\text { Strict control and critical assessment of } \\
\text { children's behavior, little dialogue (giving } \\
\text { and receiving) verbally, less warm and } \\
\text { less emotionally intertwined. } \\
\text { Does not control; not demanding; little } \\
\text { punishment or power; use of reason; }\end{array}$ & $\begin{array}{l}\text { Withdraw from the association } \\
\text { and not be satisfied and do not } \\
\text { believe in others }\end{array}$ \\
& $\begin{array}{l}\text { Less self-esteem; self-control and } \\
\text { tendency to explore. }\end{array}$ \\
Authoritative & $\begin{array}{l}\text { Control; sue; warm; repressive; rational; } \\
\text { dialogue (giving and receiving) verbally; } \\
\text { respect discipline, confidence; and } \\
\text { uniqueness. }\end{array}$ & $\begin{array}{l}\text { Mandiri; socially responsible } \\
\text { 'have self control; explorative; } \\
\text { and confidence. }\end{array}$ \\
\hline
\end{tabular}

From the table above it can be seen that democratic parenting has the characteristics of parents demanding and controlling the behavior of children, but still willing to accept opinions and provide responses if needed. While authoritarian parenting, parents tend to be more likely to sue children but do not want to accept the opinions of children. Meanwhile, permissive parenting neglects and obeys has a characteristic lack of control and rules given by parents to children, so that children become spoiled and demand everything from parents.

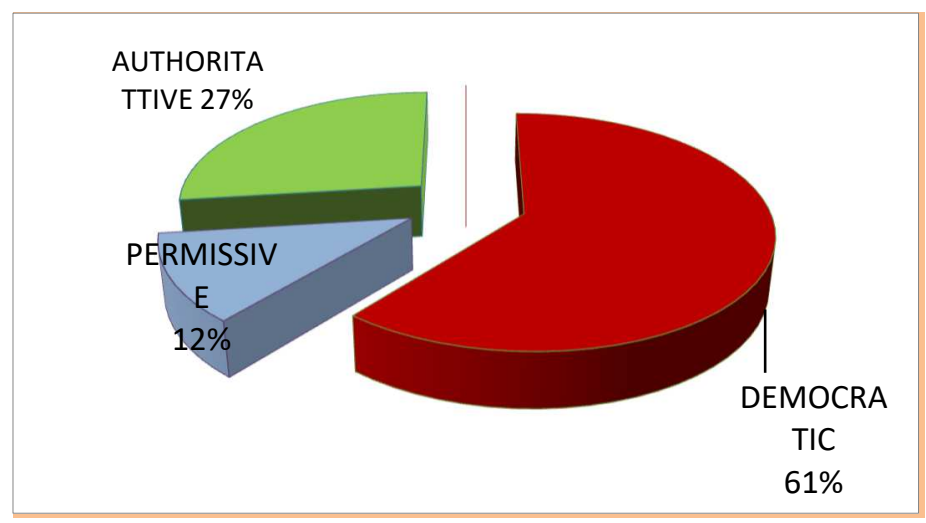

Fig. 1. Diagram Parenting Style 
Based on the circle diagram above, the variable parenting style in the authoritarian parenting category was $27 \%$, the democratic parenting category was $61 \%$ and the permissive parenting category was $12 \%$. The data shows that the tendency of parents' parenting variables is centered on democratic parenting categories.

\section{Conclusion}

The treatment of hegemony in the church environment is inseparable from parenting. Guidance applied by parents to their children relates to life, education in the church environment is also very important for the life of the child, so that the child is easy to do religious and do good for himself, the surrounding environment.

This is where the role of each party is needed to be able to actively participate in building good character for children in order for them to be able to choose the right identity as children of God, able to make choices about the relationships encountered and able to resist negative influence of information technology developing communication.

The aim of treating hegemony or power to children in the church is:

a. So that children know God as the Creator and sovereign all creation and God as their redeemer, leader and helper.

b. So that children understand their position and vocation as members of the Church of God, and love to work for the development of this earth.

c. So that children love each other because God loves them themselves.

d So that children are aware of their sins and are always willing to repent, ask forgiveness and renewal of life in God.

Parents' responsible is to love their children by teaching God's Word through actions. Parents must be ready to accompany the children in their developmental stages.

\section{References}

[1] Fontana, Banedetto. (1993). Hegemony and Power: on the Relation between gramsci and marchiavelli. University of minesota

[2] Patria, Nezar \& Andi Arief. (2003). Antonio Gramsci Negara \& Hegemoni. Yogyakarta: Pustaka Pelajar

[3] Somov, A.: Judul artikel. Jurnal ABCD. pp. 1-11 (2011)

[4] YB. Mangun Wijaya, 1986, menumbuhkan sikap Religius pada anak. Jakarta : Balai Pustaka

[5] Wiwit Wahyuning. (2003). Mengkomunikasikan Moral Kepada Anak. Jakarta : PT Elex Media Komputindo

[6] Casmini. (2007). Emotional Parenting Dasar-Dasar Pengasuhan Kecerdasan Emosi Anak. Nuansa Aksara : Yogyakarta

[7] Muhyani.2012.Pengaruh Pengasuhan Orang Tua dan Peran Guru di Sekolah terhadap Ke sadaran Religius dan Kesehatan Mental .Jakarta: Direktorat Pendidikan Tinggi Islam,Kementerian Agama RI.

[8] E.G. Homrighausen \& I.H. Enklaar, Op. Cit., hlm. 122.

[9] Sumber: Daeng Ayub Natuna (2007: 146)

[10] Baumrind (dalam Santrock, 2007: 167)

[11] Nicolas P. Woltrerstroff, Mendidik Untuk Kehidupan: Refleksi Mengenai Pengajaran dan Pembelajaran Kristen, terj. Lana Asali, Surabaya, Momentum, 2007: hlm. 285. 